\title{
HUBUNGAN KADAR TROMBOSIT, HEMATOKRIT, DAN LEUKOSIT PADA PASIEN DBD DENGAN SYOK DI MAKASSAR PADA TAHUN 2011-2012
}

\author{
Dara Ugi ${ }^{1}$, Nuraini Dharmayanti ${ }^{2}$ \\ ${ }^{1,2}$ Universitas Muhammadiyah Makassar \\ e-mail: daraugi@gmail.com
}

\begin{abstract}
In order to detect the occurrence of shock in dengue patients is difficult. Decrease in platelet levels and increased levels of hematocrit is often used as an indicator of dengue especially in the event of shock. Leukocyte levels to see whether there is leukopenia or leukocytosis. By checking levels that may help in early treatment of shock. To determine the relationship between blood platelets, hematocrit and leukocytes in patients with dengue hemorrhagic fever (DHF) and shock. The study observational analytic cross-sectional retrospective design. Samples were DHF patients who received inpatient services at the hospital. RS. Faisal, Baji Labuang RS and RS. Haji in 2011-2012 taken by using total sampling. Data were obtained from medical records and analyzed by Chi Square test. The number of samples involved in this study were 100 cases. Most samples were children aged $5-15$ years 54 people (54.0\%), male sex by the number of 52 people (52.0\%). The degree of the highest degree DHF III 40 people (40.0\%). As well as the many levels of platelets were thrombocytopenia $(<100,000 / p$ l) by 55 people (55.0\%), most were rising hematocrit levels than normal (36\%), as well as the highest levels of leukocyte levels are still normal 55 people (55,0\%). In this study the results obtained Chi Square statistical test platelet levels there is a significant relationship between shock DHF and shock ( $p=0.003)$, whereas the hematocrit levels showed different results there is no significant relationship between shock DHF and shock ( $p$ $=0.067)$ and leukocyte levels show different results there is no significant relationship between shock DHF and $\operatorname{shock}(p=0.841)$.
\end{abstract}

Keyword : Dengue Fever, platelet levels, hematocrit levels and levels of leukocytes.

\begin{abstract}
Abstrak
Untuk mendeteksi kejadian syok pada pasien DBD masih sulit. Penurunan kadar trombosit dan peningkatan kadar hematokrit sering dipakai sebagai indikator DBD khususnya pada kejadian syok. Kadar leukosit untuk melihat apakah terjadi leukopenia atau leukositosis. Dengan pemeriksaan kadar tersebut diharapkan bisa membantu penanganan syok secara dini. Tujuan penelitian ini yaitu untuk mengetahui hubungan antara kadar trombosit, hematokrit dan leukosit pada penderita demam berdarah dengue (DBD) dengan syok. Penelitian ini menggunakan observational analitik desain cross sectional retrospektif. Sampel adalah pasien DBD yang mendapat layanan rawat inap di RS. Faisal, RS Labuang Baji dan RS. Haji tahun 2011-2012 diambil dengan menggunakan teknik total sampling. Data yang diperoleh dari rekam medik, dan dianalisis dengan uji Chi Square. Jumlah sampel yang terlibat dalam penelitian ini adalah 100 kasus. Kebanyakan sampel adalah anak yang berumur 5-15 tahun sebanyak54 orang (54,0\%), berjenis kelamin laki-laki dengan jumlah 52 orang $(52,0 \%)$. Derajat DBD yang terbanyak derajat III 40 orang $(40,0 \%)$. Serta kadar trombosit yang paling banyak adalah trombositopenia $(<100.000 / \mathrm{pl})$ sebanyak 55 orang $(55,0 \%)$, kadar hematokrit terbanyak adalah meningkat lebih dari normal (36\%), serta kadar leukosit yang terbanyak kadarnya masih normal 55 orang (55,0\%). Pada penelitian ini didapatkan Hasil uji statistik Chi Square kadar trombosit terdapat hubungan bermakna antara penderita DBD syok dan tidak syok $(\mathrm{p}=0,003)$, sedangkan pada kadar hematokrit menunjukan hasil berbeda tidak terdapat hubungan bermakna antara penderita DBD syok dan tidak syok $(p=0,067)$ dan kadar leukosit menunjukan hasil berbeda tidak terdapat hubungan bermakna antara penderita DBD syok dan tidak syok $(\mathrm{p}=0,841)$.
\end{abstract}

Keyword : Demam Berdarah Dengue, kadar Trombosit, Kadar Hematokrit dan Kadar Leukosit, Status DBD. 


\section{PENDAHULUAN}

Penyakit Demam Berdarah Dengue (DBD) masih merupakan salah satu masalah kesehatan masyarakat yang utama di Indonesia, hal ini tampak dari kenyataan yang ada bahwa seluruh pada 122 daerah tingkat II, 605 daerah kecamatan dan 1800 desa/kelurahan di Indonesia. World Health Organization (WHO) mencatat negara Indonesia sebagai negara dengan kasus DBD tertinggi di Asia Tenggara.

Beberapa kajian tentang dampak ekonomi dari DHF telah dilakukan. Anakanak paling sering menderita akibat DHF dengan rata-rata lama rawat di rumah sakit sekitar 5-10 hari untuk kasus berat. ${ }^{4}$ Dilaporkan sebanyak 58.301 kasus DBD terjadi di Indonesia sejak 1 Januari hingga 30 April 2004 dan 658 kematian, yang mencakup 30 provinsi dan terjadi kejadian luar biasa (KLB) pada 293 kota di 17 provinsi. $^{6}$ Beberapa penelitian lain menunjukkan kejadian DBD lebih banyak terjadi pada anak-anak yang lebih muda dari 15 tahun.

Untuk tahun 2005, jumlah penderita DBD di Makassar sebanyak 2.975 dengan kematian 57 orang. Dan pada tahun 2006 sebanyak 2.426 kasus. Pada tahun 2007 kasus DBD kembali meningkat dengan jumlah kasus sebanyak 5.333 kasus dan jumlah kasus yang terbesar berada di kab. Bone (1030) kasus, menyusul Kota Makassar (452) kasus, Kab. Bulukumba (376) kasus, Kab. Pangkep (358) kasus.

Demam berdarah atau demam berdarah dengue adalah penyakit fibril akut yang ditemukan di daerah tropis dengan penyebaran geografis yang mirip dengan malaria. Penyakit ini disebabkan oleh salah satu dari empat serotipe virus dari genus Flavivirus, family Flaviviridae. Virus ini mempunyai empat serotype yang dikenal dengan DEN-1, DEN-2, DEN-3, dan DEN-4, keempat serotype ini menimbulkan gejala yang berbeda-beda, jika menyerang manusia. Serotype yang menimbulkan infeksi paling berat di Indonesia yaitu DEN-3. Setiap serotip cukup berbeda sehingga tidak ada proteksi-silang dan wabah yang disebabkan oleh beberapa serotype (hiperendemisitas) dapat terjadi. Demam berdarah disebarkan kepada manusia oleh nyamuk Aedes aegepti.,

Demam berdarah dengue (DHF) ditandai oleh empat manifestasi klinis utama yaitu demam tinggi, fenomena hemoragik, sering dengan hepatomegali dan pada kasus berat, tanda-tanda kegagalan sirkulasi. Pasien ini dapat mengalami syok hipovolemik yang diakibatkan oleh kebocoran plasma. Syok ini disebut sindrom syok dengue dan dapat menjadi fatal. ${ }^{4}$ Demam berdarah yang berlanjut menjadi syok merupakan masalah serius pada anak. Hadinegoro melaporkan bahwa prevelensi syok pada demam berdarah dengue di seluruh rumah sakit di Indonesia mencapai 16\%- 40\% dengan angka kematian 5,7\%. Sebagian besar kematian terjadi karena syok dan syok berulang. Mayyeti (2010) melaporkan bahwa syok pasien DBD di RS DR M. Djamil padang pada tahun 2007 sebesar $46 \%{ }^{5}$

Pemeriksaan Laboratorium sederhana seperti darah rutin sering dilakukan dalam pelayanan sehari-hari untuk penegakan diagnosis maupun pngelolahan pasien. Kadar hematokrit adalah konsentrasi (dinyatakan dalam persen) eritrosit dalam $100 \mathrm{ml}$ darah lengkap. Dengan demikian kadar hematokrit adalah parameter hemokonsentrasi serta perubahannya. Kadar hematokrit akan meningkat saat terjadinya peningkatan hemokonsentrasi, baik oleh peningkatan kadar sel darah atau penurunan kadar plasma darah, misalnya pada kasus hipovolemia. Sebaliknya kadar hematokrit akan menurun ketika terjadi penurunan hemokonsentrasi, karena penurunan kadar seluler darah atau peningkatan kadar plasma darah seperti pada terjadinya anemia. ${ }^{4}$ Trombositopenia merupakan salah satu kriteria laboratorium non spesifik untuk menegakkan diagnosis DBD yang ditetapkan oleh WHO. ${ }^{4}$ Hasil penelitian Shah GS dkk ${ }^{6}$ tahun 2006 di 
Bangladesh, menunjukkan dari 100 penderita anak-anak yang positif infeksi dengue, $52 \quad(61,7 \%)$ menunjukkan trombositopenia pada penderita DBD dan DSS (Dengue Syock Syndrome).

Berdasarkan uraian tersebut maka perlu dilakukan penelitian untuk mengetahui apakah "Hubungan antara Kadar Trombosit, Hematokrit, Leukosit pada Pasien Dbd Dengan Syok Di Rumah Sakit di Makassar".

\section{METODE}

Desain penelitian yang akan digunakan dalam proses penelitian adalah studi cross sectional pada pasien demam berdarah dengue (DHF) yang dirawat di Rumah Sakit, dengan mengukur kadar trombosit, hematokrit dan leukosit pada pasien DBD. Pasien yang diikutkan pada penelitian ini adalah pasien yang didiagnosa dengan DHF berdasarkan pemeriksaan trombosit, hematokrit dan leukosit. Kemudian pasien diikuti di rekam medis apakah berkembang menjadi syok. ${ }^{1}$ Penelitian ini akan dilaksanakan di Makassar.

Populasi dan sampel dalam penelitian ini adalah semua anak penderita demam berdarah dengue yang dirawat di Makassar Tahun 2011-2012. Penelitian ini menggunakan data pasien Demam Berdarah Dengue dari beberapa rumah sakit yaitu RSI Faisal, RS Labuang Baji dan RS Haji tahun 2011-2012. Penelitian ini berlangsung selama 3 minggu terhitung mulai tanggal 21 Desember 2012 hingga tanggal 11 Januari 2012. Jumlah keseluruhan pasien demam berdarah dengue dari tiga rumah sakit yang dirawat inap adalah 100 orang. Subjek penelitian ini diambil semua, total sampling yang telah memenuhi kriteria inklusi dan ekslusi. Kriteria inklusi pasien yaitu berusia maksimal 15 tahun, pasien dirawat inap di bagian rumah sakit di Makassar tahun 2011-2012, didiagnosis demam berdarah dengue oleh dokter, memiliki catatan medik yang lengkap dengan pemeriksaan darah lengkap yang mencakup pemeriksaan kadar trombosit, kadar hematokrit dan kadar leukosit. Kriteria eksklusi yang masing-masing memiliki persyaratan yaitu pasien yang menderita penyakit penyerta lainnya dan pasien dengan penyakit konsiden lain yang dapat mempengaruhi hasil perhitungan darah, misal penyakit demam thypoid. Data yang diperoleh kemudian diolah dan disajikan dalam bentuk tabel frekuensi dan tabulasi silang sesuai dengan tujuan penelitian

Jenis dan Cara Pengumpulan Data data yang dikumpulkan meliputi data sekunder di ambil dari catatan rekam medik pasien yang didiagnosis DBD yang dirawat berupa nama pasien, umur pasien, jenis kelamin serta derajat DBD tanpa syok atau dengan syok serta kadar trombosit, hematokrit dan leukosit pada pasien DBD di rumah sakit di Makassar tahun 20112012. Penelitian ini dilakukan dengan melihat status pasien (rekam medik) mengenai kasus DBD yang dirawat inap rumah sakit di Makassar dari bulan November 2011 sampai bulan November 2012 yang di diagnosis DBD oleh dokter yang merawat yang dipindahkan dalam daftar cheklist. Pengumpulan dan Pengelolahan data penderita DBD dibedakan menjadi 2 kelompok yaitu kelompok penderita DBD non syok dan penderita DBD dengan syok. Adapun data yang diperoleh dari kedua kelompok meliputi: umur, jenis kelamin, hasil pemeriksaan darah, hari sakit, lama perawatan semua data yang diperlukan diambil pada saat pasien masuk rumah sakit dengan demam hari ke-3. Pengelolahan data dikumpulkan melalui daftar checklist akan diolah menggunakan program Statistik. Analisis Data selanjutnya dianalisis dengan menggunakan analisis univariat dan bivariat.

\section{HASIL DAN PEMBAHASAN}

\section{Distribusi Subjek Berdasarkan Karakteristik Klinik}


Tabel 1. Distribusi Subjek Berdasarkan Karakteristik Klinik

\begin{tabular}{|c|c|c|c|c|}
\hline No & Variabel & Sub Grup & $\mathbf{n}$ & Jumlah Persentase (\%) \\
\hline \multirow{4}{*}{1} & \multirow{4}{*}{ Derajat Berat Penyakit DBD } & $\mathrm{I}$ & 34 & 34,0 \\
\hline & & II & 16 & 16,0 \\
\hline & & III & 40 & 40,0 \\
\hline & & IV & 10 & 10,0 \\
\hline \multirow{2}{*}{2} & \multirow{2}{*}{ Status DBD } & Shock & 50 & 50,0 \\
\hline & & Tidak shock & 50 & 50,0 \\
\hline
\end{tabular}

Sumber : Unit Rekam Medik RS Makassar

Berdasarkan tabel distribusi karakteristik klinik pasien dari tabel 5.1 dapat dilihat, karakteristik pada derajat beratnya DBD, penderita dengan derajat III sebanyak 40 orang dengan presentase sebesar $40,0 \%$, derajat I sebanyak 34 orang dengan presentase sebesar $34,0 \%$, derajat II sebanyak 16 orang dengan presentase sebesar $16,0 \%$ dan derajat IV sebanyak 10 orang dengan presentase sebesar $10,0 \%$. Hal ini menunjukan bahwa kebanyakan pasien DBD dengan derajat III presentase sebesar 40,0\%. Dari 100 penderita status DBD didapatkan rasio penderita yang mengalami DBD yang syok dan tidak syok dalam penelitian ini 1:1 atau berbanding sama dimana terdapat
50 orang syok dan 50 orang yang penderita DBD tidak syok.

\section{Distribusi Subjek Berdasarkan Karakteristik Laboratorium}

Trombositopenia adalah penyebab terjadinya pendarahan. Tetapi pada pasien Demam Berdarah Dengue yang mengalami trombositopenia tidak selalu disertai dengan pendarahan. Apabila kadar trombosit seseorang kurang dari $100.000 / \wedge 1$ maka dikatakan mengalami trombositopenia. Pada pasien Demam Berdarah Dengue dapat terjadi leukopenia. Yakni nilai leukosit kurang dari nilai normal.

Tabel 2. Distribusi Subjek Berdasarkan Karakteristik Laboratorium

\begin{tabular}{ccccc}
\hline No & Variabel & Sub Grup & n & Jumlah Persentase (\%) \\
\hline 1 & Kadar Trombosit & $<100.000($ Trombositopenia & 55 & 55,0 \\
\hline & & Normal $(>100.000)$ & 45 & 45,0 \\
\hline 2 & Kadar Hemotokrit & $<36$ & 41 & 41,0 \\
\hline & & $>36$ & 59 & 59,0 \\
\hline 3 & Kadar Leukosit & $<5000$ (leukopenia) & 45 & 45,0 \\
\hline & & $>5000$ (Normal) & 55 & 55,0 \\
\hline
\end{tabular}

Sumber : Unit Rekam Medik RS Makassar

Pada tabel diatas menunjukkan bahwa subjek pada penelitian ini kebanyakan pada kadar trombosit kebanyakan nilainya berada $<100.000$ atau trombositopenia sebanyak 55 orang dengan presentase sebesar 55,0\%. Pada kadar hematokrit kebanyakan nilainya $>36$ dimana sebanyak 59 orang dengan presentase sebesar 59,0\%. Sedangkan pada kadar leukosit masih dalam kadar $>5000$ dimana sebanyak 55 orang dengan presentase sebesar $55,0 \%$.

Hubungan Antara Kadar Trombosit, 


\section{Hematokrit dan Leukosit Dengan Kejadian Syok Pada DBD}

Untuk melihat hubungan antara kadar trombosit, hematokrit dan leukosit dengan kejadian syok pada pasien DBD yang dirawat di beberapa Rumah Sakit di Makassar pada tahun 2011-2012 dapat dilihat pada tabel dibawah ini. Apabila kadar trombosit $<100.000 / \wedge 1$ disebut trombositopenia. Leukopenia apabila kadar leukosit $<5000$ adalah pertanda dalam 24 jam kemudian demam akan turun dan pasien akan masuk dalam masa kritis.
Pada tabel 5.5 terlihat bahwa pada kadar trombosit pada kelompok syok kadarnya adalah $<100.000 /$ pl sebanyak 35 pasien dengan presentase sebesar $63,6 \%$, sedangkan yang nilai trombositnya normal sekitar 15 pasien dengan presentase $33,3 \%$. Dan pada kelompok tidak syok kadar trombosit terbanyak dalam keadaan normal sekitar 30 orang dengan presentase $66,7 \%$, sedangkan nilai trombosit dengan nilai $<100.000 /$ pl sebanyak 20 pasien dengan presentase $36,4 \%$, dengan nilai $\mathrm{P}$ value dari kadar trombosit sebesar 0,003 .

Tabel 3. Hubungan Antara Kadar Trombosit, Hematokrit dan Leukosit Dengan Kejadian Syok DBD

\begin{tabular}{|c|c|c|c|c|c|c|c|c|c|}
\hline \multirow{2}{*}{ No } & \multirow{2}{*}{ Variabel } & \multirow{2}{*}{ Sub Grup } & \multicolumn{2}{|c|}{ Syok } & \multicolumn{2}{|c|}{ Tidak Syok } & \multirow{2}{*}{ Value } & \multirow{2}{*}{ OR } & \multirow{2}{*}{$\mathrm{C} \%$} \\
\hline & & & $\mathrm{n}$ & $\%$ & $\mathrm{n}$ & $\%$ & & & \\
\hline \multirow{2}{*}{1} & \multirow{2}{*}{ Kadar Trombosit } & $<100.000$ & 35 & 63,6 & 20 & 36,4 & \multirow{2}{*}{0,003} & \multirow{2}{*}{3,500} & \multirow{2}{*}{$1,529-8,012$} \\
\hline & & $>100.000$ & 15 & 33,3 & 30 & 66,7 & & & \\
\hline \multirow{2}{*}{2} & \multirow{2}{*}{ Kadar Hemotokrit } & $<36$ & 16 & 39,0 & 25 & 61,0 & \multirow{2}{*}{0,067} & \multirow{2}{*}{0,471} & \multirow{2}{*}{$0,209-1,061$} \\
\hline & & $>36$ & 34 & 57,6 & 25 & 42,4 & & & \\
\hline \multirow{2}{*}{3} & \multirow{2}{*}{ Kadar Leukosit } & $<5000$ & 22 & 48,9 & 23 & 51,1 & \multirow{2}{*}{0,841} & \multirow{2}{*}{0,040} & \multirow{2}{*}{$0,419-2,028$} \\
\hline & & $>5000$ & 28 & 50,9 & 27 & 49,1 & & & \\
\hline
\end{tabular}

Sumber : Unit Rekam Medik RS Makassar

Kadar hematokrit pada kelompok syok terbanyak kadar hematokritnya $>36 \%$ sebanyak 34 pasien dengan presentase $57,6 \%$ sedangkan pada kelompok tidak syok pasien dengan kadar hematokritnya $<36 \%$ sebanyak 25 pasien dan dengan kadar $>36 \%$ sebanyak 25 pasien pula. Namun presentase tertinggi pada kelompok tidak syok dengan nilai $<36 \%$, sebesar $61,0 \%$ dan kadar $>36 \%$ sebanyak $42,4 \%$, dengan $\mathrm{P}$ value nilai kadar hematokrit sebesar 0,067. Kadar leukosit, pada kelompok syok kebanyakan kadar leukosit yang normal, yakni sebanyak 28 pasien dengan presentase 50,9\%, sedangkan pasien yang mengalami leukopenia sebanyak 22 pasien dengan presentase 48,9\%. Hal ini sama dengan pasien pada kelompok tidak syok, yakni sebesar 27 orang dengan presentase $51,1 \%$. Sedangkan pasien yang mengalami leukopenia 23 pasien dengan presentase 49,1\%. Dengan nilai $\mathrm{P}$ value pada kadar leukosit sebesar 0,841 .

Tabel 4. Kekuatan Hubungan Asosiasi Antara Masing-Masing Variabel Uji Bivariat

\begin{tabular}{llll}
\hline Hubungan AntarVariabel & p Value & OR & CI(\%) \\
\hline Kadar Trombosit dengan Status DBD & 0,003 & 3500 & $1,529-8,012$ \\
\hline Kadar Hematokrit dengan Status DBD & 0,067 & 0.471 & $0,209-1,061$ \\
\hline Kadar Leukosit dengan Status DBD & 0,841 & 0,040 & $0,419-2,028$ \\
\hline Sun
\end{tabular}

Sumber : Unit Rekam Medik RS Makassar 
Berdasarkan tabel diatas, pada kolom hubungan antara kadar trombosit dengan status DBD nilai P 0,003 yang berarti Ho ditolak atau ada hubungan yang bermakna antara kadar trombosit dengan status DBD karena didapatkan nilai $\mathrm{P}<0,05$. Pada kolom hubungan antara kadar hematokrit dengan status DBD nilai $\mathrm{p} 0,067$ yang berarti tidak ada hubungan yang bermakna antara kadar hematokrit dengan ststus DBD karena didapatkan nilai $\mathrm{P}>0,05$. Sedangkan pada kolom hubungan antara kadar leukosit dengan status DBD nilai $\mathrm{p}$ 0,841 yang berarti tidak ada hubungan yang bermakna antara kadar hematokrit dengan ststus DBD karena didapatkan nilai $\mathrm{P}>0,05$.

Dari hasil penelitian didapatkan sebanyak 45 pasien $(45,0 \%)$ yang menunjukan kadar leukosit awal $<5000 / \mathrm{mm}$ (leukopeni) dan sisanya sebanyak 55 pasien $(55,0 \%)$ yang menunjukan kadar leukosit awal $>5000 / \mathrm{mm}$. Dalam penelitian ini didapatkan pasien dengan kadar leukosit awal $<5000 / \mathrm{mm}$ sebanyak 22 pasien pada kelompok syok dan 23 pada kelompok tidak syok.

Sebanyak $56,0 \%$ pasien DBD mengalami trombositopenia ( trombosit dibawah $100.000 /{ }^{\wedge} 1$ ) dari semua pasien yang mengalami trombositopenia 35 orang pada kelompok syok dan 20 orang pada kelompok tidak syok. Hubungan trombositopenia dengan kejadian syok pada penelitian ini bermakna $(p=0.003)$. Hal ini sesuai dengan hasil penelitian Mayetti bahwa pasien syok dengan nilai trombosit $<100.000$ lebih banyak sebesar 86 orang atau 62,2\%. Penelitian sebelumnya menemukan hubungan yang bermakna dari trombositopenia dalam memprediksikan syok. ${ }^{36}$ Hal ini Berbeda dengan penelitian Ahmad Taufik, dkk tidak menemukan hubungan yang bermakna $\quad(p=0,218) \quad$ antara trombositopenia dengan syok.

\section{Pembahasan}

Diagnosis penyakit DBD dan jumlah perjalanan penyakit harus dilakukan secara tepat dan akurat. Pada demam berdarah dengue (DBD), pemeriksaan laboratorium menunjukan trombositopenia dan hematokonsentasi. ${ }^{9}$ Jumlah trombosit dan kadar hematokrit sering digunakan sebagai indikator berat tidaknya penyakit tersebut. Oleh karena itu pemeriksaan darah merupakan hal mutlak dilakukan ${ }^{29}$.

Pada pemerikasaan laboratorium dijumpai jumlah trombosit dan peningkatan hematokrit. Jumlah trombosit kurang dari $100.000 / \mathrm{mmm}$, biasanya ditemukan antara hari sakit ke tiga sampai hari ke tujuh. Pemeriksaan trombosit perlu diulang sampai terbukti bahwa dalam batas normal atau menurun. Peningkatan hematokrit $(\mathrm{Ht})$ atau hematokonsentrasi yang selalu dijumpai pada DBD merupakan indikator yang peka akan terjadinya perembesan plasma, sehingga dilakukan pemeriksaan hematokrit secara berkala. Pada DBD, jumlah sel darah putih mungkin bervariasi pada awal penyakit, berkisar dari leucopenia sampai leukositosis ringan. ${ }^{4}$

Faktor-faktor yang dapat mempengaruhi terjadinya trombositopenia pada penderita DBD yaitu adanya pelepasan sitokin kedalam sirkulasi selama fase awal demam akut dari infeksi dengue. sitokin tersebut antara lain tumour necrosis factor (TNF-_), interleukins (IL-2, IL-6, IL-8) dan interferon (IFN). Kadar sitokin tersebut berhubungan dengan derajat berat DBD. Waktu terjadinya supresi sumsum tulang juga berhubungan dengan peningkatan kadar sitokin dalam darah. ${ }^{31-}$ 34

Trombositopenia pada DBD antara lain disebabkan oleh adanya destruksi trombosit dalam sistem retikuloendotel, pemendekan waktu paruh trombosit, adanya depresi sumsum tulang, perubahan patologis pada sistem megakariosit, peningkatan pemakaian faktor-faktor 
pembekuan dan trombosit dan koagulasi intravascular. Hemokonsentrasi antara lain disebabkan oleh kebocoran plasma, kurangnya asupan cairan dan kehilangan cairan akibat demam. ${ }^{30}$

Saat kebocoran plasma berupa rentan waktu yaitu hari ketiga sampai ketujuh. Hematokrit yang tinggi dihubungkan dengan kebocoran plasma yang berperan penting dalam patogenesis terjadinya syok. Kadar hematokrit pada pasien DBD mengalami peningkatan $20 \%$ secara bermakna dengan status DBD. Pada Penelitian ini jumlah pasien yang mengalami hematokonsentrasi (peningkatan hematokrit lebih dari 20\%) ada 59 orang $(59,0 \%)$.

Hal ini Bedasarkan pada jumlah pasien yang mengalami peningkatan hematokrit diatas $36 \%$. Syok pada penelitian ini lebih sering ditemukan pada kadar hematokrit meningkat dari normal pada saat awal masuk rumah sakit, tetapi secara umum statistik hal tersebut menjadi tidak bermakna $(p=0,067)$. Hal ini bisa disebabkan pada pengambilan sampel yang dimulai hari ketiga, padahal belum tentu pada hari ketiga merupakan puncak kebocoran plasma, sehingga kadar hematokrit yang diperiksa belum bisa dilihat apakan mengalami peningkatan $20 \%$. Karena untuk mengetahui kadar hematokrit mengalami peningkatan harus dipantau/difollow up selama dirawat di Rumah Sakit.

Hasil penelitian ini sama dengan penelitian Taufik et $\mathrm{al}^{37}$. yang menemukan bahwa kadar hematokrit dan jumlah trombosit tidak dapat dipergunakan untuk memprediksi terjadinya syok pada pasien infeksi dengue. Dewi et al. juga berpendapat bahwa kadar hematokrit tidak dapat dipergunakan sebagai faktor untuk memprediksi kejadian syok, namun trombositopenia dapat dipergunakan.

Pada DBD, jumlah darah sel darah putih mungkin bervariasi pada awitan penyakit, berkisan dari leukopenia sampai leukositosis ringan, tetapi penurunan sel darah putih total karena penurunan pada jumlah netrofil secara nyata selalu terlihat mendekati akhir fase demam. ${ }^{4}$ Terjadinya leukopeni pada infeksi dengue disebabkan karena adanya penekanan sumsum tulang akibat dari proses infeksi virus secara langsung ataupun karena mekanisme tidak langsung melalui produksi sitokin-sitokin proinflamasi yang menekan sumsum tulang. ${ }^{39}$

Sitokin atau mediator adalah semua produk sel yang meliputi produk dari monosit, limfosit atau sel yang lain. Sitokin memegang peran dalam terjadinya kebocoran vaskuler, karena dapat menyebabkan aktifasi endotel. Nama produknya bermacam-macam yaitu interleukin, limfokin, monokin, TNF (tumor necrosis faktor). ${ }^{40,41,42}$, Kemokin adalah sitokin yang berperan dalam kemotaksis sel-sel leukosit(limfosit,monosit, dan neutrofil) ke tempat infeksi atau kerusakan jaringan. Sitokin terutama diproduksi oleh monosit/makrofag dan sel-sel lain seperti sel endotel, trombosit, neutrofil, sel $\mathrm{T}$, keratinosit dan fibroblas sebagai respon terhadap proses infeksi atau kerusakan fisik. $^{43}$

Berpindahnya sel fagosit dari vaskuler ke jaringan akan menyebabkan permeabilitas dinding pembuluh darah meningkat sehingga cairan vaskuler yang keluar semakin banyak. Hal ini dapat mengakibatkan terjadinya syok. Dalam penelitian ini, tidak dilakukan pengamatan terhadap mediator atau sel fagosit seperti monosit, makrofag, dan sel PMN (neutrofil). Pengamatan dilakukan terhadap jumlah leukosit.

Sedangkan pasien dengan kadar leukosit awal $>5000 / \mathrm{mm}$ sebanyak 28 pasien pada kelompok syok dan 27 pasien pada kelompok tidak syok. Hubungan kadar leukosit dengan kejadian syok pada penelitian ini tidak bermakna $(p=0,841)$. Hasil penelitian ini berbeda dengan penelitian Bima Valentino ${ }^{44}$ bahwa terdapat hubungan bermakna antara jumlah leukosit dengan derajat klinik infeksi dengue $(\mathrm{p}=0,033)$. 


\section{KESIMPULAN}

Berdasarkan hasil analisis data nilai $\mathrm{p}$ diketahui $p=0,003, p=0,067, p=0,841$ yaitu nilai $\mathrm{p}$ kadar trombosit, Kadar hematokrit dan Kadar leukosit secara berturut-turut. Ini mengindikasikan bahwa kadar trombosit berpengaruh dengan risiko syok Pada penderita DBD anak berumur 5-15 tahun. Kadar hematokrit dan kadar leukosit tidak terdapat hubungan bermakna dengan kejadian syok Pada penderita DBD anak.

\section{DAFTAR PUSTAKA}

1. Pustaka Kesehatan Populer: Mengenai Berbagai Macam Penyakit Infeksi. Ed.9. PT Bhuana Ilmu Populer; 186189

2. Buku kuliah Ilmu Kesehatan Anak 2. Jakarta:Universitas Indonesia; 608

3. Hindra I Satari, Mila Meiliasari. Demam Berdarah, Perawatan di Rumah dan Rumah Sakit+Menu. Jakarta: Puspa Swara, Anggota IKAPI.2008.

4. Word Health Organization (WHO). Demam Berdarah Dengue, diagnosis: pengobatan, pencegahan dan pengendalian. 2nd ed. Jakarta: EGC; 1999.

5. Sari Pediatri. 2010. Hubungan Gambaran Klinis dan Laboratorium Sebagai Faktor Risiko Syok pada Demam Berdarah Dengue. https://docs.google.com/viewer? $a=v \&$ $q=$ cache:Zgwi7zOsQMJ:www.idai or.id. Diakses tanggal 26 September 2012.

6. Aryati. Aspek laboratorium DBD Dengan Permasalahan dan Interpretasinya. Muswil V Patelki. Malang: 2005.

7. Halsread SB, Scanlon JE, Unpaivit P. Dengue and chikungunya virus infection in man in Thailand, 19621964. Am $J$ Trop Med Hyg 1969;18:997-1s021.

8. Dinkes Provinsi Sul-Sel..Profile
Kesehatan Provinsi Sulawesi Selatan.Penerbit Kesehatan Provinsi Sulawesi Selatan. Makassar,2010.

9. Soegeng Soegijanto. Demam Berdarah Dengue 2,,d. Surabaya: Airlangga Universitas Press: 2008.

10. Inge Sutanto, dkk. Buku ajarparasitologi.ed 4. Jakarta: FKUI.2010-2011.

11. Sutjana, Primal. Demam Berdarah Dengue di Indonesia Tahun 19682009. Buletin Jendela Epidemologi ed Agustus Volume II. 2010.

12. Anto Sitio. Hubungan Perilaku Tentang Pemberantasan Sarang Nyamuk Dan Kebiasaan Keluarga Dengan Angka Kejadian Demam Berdarah Dengue Tahun 2008. Undip. Semarang.

13. Widoyono. Penyakit Tropis: epidemologi, Penularan, Pencegahan dan pemberantasannya. 2nd. Jakarta: Erlangga.2010-2011.

14. CDC. Epidemologi Dengue. Demam Berdarah Dengue. http://www.cdc.gov/dengue/epidemolo gy/index.html. 2010-2011. Diakses tanggal 20 September 2012.

15. Hadinegoro, sri $R$, Soegijanto, Soegeng. Departemen kesehatan dan Kesejhrataan social RI. Tatalaksana demam berdarah dengue di Indonesia. Jakarta: Depkes RI; 2001

16. Suhendro, Naigolan L, Khiechen. Ilmu penyakit dalam. Jakarta: Departemen Ilmu Penyakit Dalam. FKUI;2007.

17. Hillman $R S$, Ault $K$ A, Rinder, Henry $M$. . Hematology in Clinical Practice $4^{\text {th }}$ ed. New York: McGraw-Hill Companies; 2005.

18. Tumbelaka AR, Darwis D, Gatot D, Pramulyo $H \quad S$, Zulkarnain I, Timmbunan K.dkk. Demam Berdarah Dengue naska lengkap pelatihan bagian pelatih dokter sesialis anak, dokter spesialis penyakit dalam, dalam tatalaksana kasus DBD. Jakarta: FKUI;1999.

19. Soegijianto, S. Demam Berdarah 
Dengue Pada Bayi. Surabaya. Indonesia: 1999/2000.

20. Soedarno Sp. Masalah demam berdarah dengue di Indonesia. Dalam: Hadinegoro SRS. Satari HI, Penyunting. Demam Berdarah Dengue. Naskah Lengkap Pelatihan NAgi Dokter Spesialis Anak dan Dokter Spesialis Penyakit Dalam Tatalaksana Kasus DBD. Jakarta: Balai Penerbit Fakultas Kedokteran Universitas Indonesia; 1999. H1-12. Dalam Raihan, dkk. Faktor Prognosis Terjadinya Syok Pada Pasien Demam Berdarah Dengue. Saripediatri (Onlina) edisi 2010. Vol 12, No 1 Juni 2010

21. Yenni Risniati, Lukman Hakim Tarigan, Emiliana Tjitra. Leukopenia Sebagai Predikator Terjadinya Sindrome Syok Dengue. [skripsi] di depok. Media Litbang Kesehatan. Available from: http:// Fejournal.litbang.depkes.go.id/ Findex.php/ FarticleFdownload.

22. Wati WE. Beberapa Faktor Yang Berhubungan dengan kejadian demam berdarah dengue (dbd) di kelurahan ploso kecamatan pacitan tahun 2009 [skripsi]. Surakarta: Universitas muhammadiyah Surakarta; 2009 [mei 2011].

23. Krishnamurti $C$, Kalayanarooj $S$, Cutting M, Peat RA, Rothwell SW, Reid T, et al. Mechanicms of hemorrhage in dengue without circulatory collapse. Am J Trop Med Hyg, 2002. (cited 2012 July 17)..

24. Suhendro, Naigolan L, Khiechen. Ilmu penyakit dalam. Jakarta: Departemen Ilmu penyakit dalam. FKUI;2007

25. Gatot D. Perubahan hematologi pada infeksi dengue. Dalam: Hadinegoro SRH, Satari HI, editors. Demam berdarah dengue. 1st ed. Jakarta: Balai Penerbit FKUI; 2000.

26. Hendarwanto. Dengue. Dalam: Sjaifoellah $N$, editor. Buku ajar penyakit dalam. Jilid I. $3 r d$ ed.
Jakarta: Balai penerbit FKUI; 1997.

27. Krisnamurti $C$, Kalayanarooj $S$, Cutting MA, Peat RA, Rothwell SW, Reid TJ, et al. Mechanism of hemorrhage in dengue without circulatory collapse. Am J Trop Med Hyg 2001.

28. Hadinegoro SR. Soegijanto $S$, Wuryadi S, Suroso T. Tatalaksana demam berdarah/demam berdarah dengue pada anak. Dalam: Hadinegoro SRH, Satari HI, editors. Demam berdarah dengue. 1 st ed. Jakarta: Balai Penerbit FKUI; 2000.

29. Hadinegoro SR, Soegijanto S, Wuryadi S, Suroso T, editor. Tatalaksana demam berdarah dengue di Indonesia. Jakarta: Direktorat Jenderal Pemberantasan Penyakit Menular dan Penyehatan Lingkungan. 2006.

30. Margareta Diana. Korelasi Antara Trombositopenia dengan Hematokonsentrasi sebagai faktor predisposisi Terjadinya Syok pada pasien dewasa (Internet). 2007. Juni.

31. http://www.pdii.lipi.go.id/jurnal/1109 5056.pdf/jurnal demam berdarah dengue.

32. Mayetti. Hubungan Gambaran klinia dan Laboratorium sebagai faktor Risiko Syok pada Demam Berdarah Dengue. Saripediatri. Vol.11.No 5. Febuari 2010.

33. Srichaikul $T$, Nimmanitya $S$. Haematology in dengue and dengue hemorrhagic fever. Bailliere's Clinical Haematology 2000;13(2):261-76. Dalam Anak Agung Ngurah Subawa, I Wayan Putu Sutirta Yasa .Pola Jumlah Trombosit Penderita Demam Berdarah Dengue (Dbd) Pada AnakAnak Yang Petanda Serologinya Positif. [Skripsi]. J Peny Dalam. Vol 8, No 3 Sepember 2007.

34. Murgue B, Cassar O, Deparis $X$. Impication of macrophage inflammatory protein 1 alfa in the inhibition of human haematopoietic progenitor growth by dengue virus. J 
Gen Virol 1998;79:1889-93. Dalam Anak Agung Ngurah Subawa, I Wayan Putu Sutirta Yasa. Pola Jumlah Trombosit Penderita Demam Berdarah Dengue (Dbd) Pada AnakAnak Yang Petanda Serologinya Positif. [Skripsi]. J Peny Dalam. Vol 8, No 3 Sepember 2007.

35. Mitrakul C. Bleeding Problems in dengue hemorrhagic fever: Platelet and coagulation changes. Southeast Asian. J Trop Med Pub Health 1987;18(13):407-12. Dalam Anak Agung Ngurah Subawa, I Wayan Putu Sutirta Yasa .Pola Jumlah Trombosit Penderita Demam Berdarah Dengue (Dbd) Pada Anak-Anak Yang Petanda Serologinya Positif. [Skripsi]. J Peny Dalam. Vol 8, No 3 Sepember 2007.

36. Huang KJ, Li SYJ, Chen SC, Liu HS. Manifestation of thrombocytopenia in dengue-2 virus infected mice. $J$ Gen Virol 2000;81:2177-82. Dalam Anak Agung Ngurah Subawa, I Wayan Putu Sutirta Yasa. Pola Jumlah Trombosit Penderita Demam Berdarah Dengue (Dbd) Pada Anak-Anak Yang Petanda Serologinya Positif. [Skripsi]. J Peny Dalam. Vol 8, No 3 Sepember 2007.

37. Dewi, Rismala, Roland. Clinical features of dengue hemorrhagic fever and risk factors of shock event. Paediatrica Indonesiana 2006;46:144. Dalam Ahmad Taufik, dkk. Peranan kadar hematokrit, jumlah trombosit dan serologis IgG-IgM anti DHF dalam memprediksi terjadinya syok pada pasien demam berdarah Dengue di Rumah Sakit Islam Siti Hajar. J Peny Dalam. 2007.

38. Ahmad Taufik, dkk. Peranan kadar hematokrit, jumlah trombosit dan serologis IgG-IgM anti DHF dalam memprediksi terjadinya syok pada pasien demam berdarah Dengue di Rumah Sakit Islam Siti Hajar. J Peny Dalam. 2007. Dalam Dikcy Santosa,dkk. Validitas Kaar Laktat Darah dalam Mendeteksi Kebocoran Plasma pada Infeksi Virus Dengue
Anak. Bandung: Universitas Padjadjaran. 2011.

39. Dewi R, Tumbelaka AR, Sjarif DR. Clinical features of dengue hemorrhagic fever and risk factors of shock event. Paediatri Indonesia. 2006. Dalam Dikcy Santosa,dkk. Validitas Kadar Laktat Darah dalam Mendeteksi Kebocoran Plasma pada Infeksi Virus Dengue Anak. Bandung: Universitas Padjadjaran. 2011.

40. A Rena, Ni Made, Susila Utama, Tuti Parwati M. Kelainan hematologi pada demam berdarah dengue. FK Unud RSUP Sanglah Denpasar. Jurnal Penyakit Dalam, Volume 10 Nomor 3. 2009.

41. Sutarjo. Dengue. Yogyakarta: Medika Fakultas Kedokteran UGM, 2004. Dalam Fiyya Aglilatun. Hubungan Antara Jumlah Leukosit Dengan Kejadian Syok Pada Penderita DBD Dewasa [skripsi] di Semarang. From: eprint.undip.ac.id/22679/1/Fiyya.pdf. Diakses pada 29 Desember 2011.

42. Anastasia Ratnaningsih. Skor Kebocoran Vaskuler Sebagai Penanda Awal Terjadinya Syok Pada Demam Berdarah Undip.Semarang.2005.

43. Bratawidjaja, Karnen Gama. Imunologo Dasar Edisi ke-6. Jakarta: Balai Penerbit Fakultas Kedokteran Indonesia, 2004. Dalam Fiyya Aglilatun. Hubungan Antara Jumlah Leukosit Dengan Kejadian Syok Pada Penderita DBD Dewasa [skripsi] di Semarang. $\quad$ From: eprint.undip.ac.id/22679/1/Fiyya.pdf. Diakses pada 29 Desember 2011.

44. Bima Valentino. Hubungan Antara Hasil Pemeriksaan Darah Lengkap Dengan Derajat Klinik Infeksi Dengue Pada Pasien Dewasa. FK Universitas Diponegoro. Jurnal Media Medika Muda. 2011. 